\title{
Lifelong Learning from a British Political Perspective: The Case of the University for Industry
}

\begin{abstract}
:
This article purports to account for the British government's resort to sell Ufi ltd to a private group of investors in 2011-after more than a decade of strenuous official efforts (both political and financial) to make of it a higher education success story. The central argument is that New Labour politicians' superficial interpretation of the concept of lifelong learning, due to their tight market-economy partypolitical agenda, has caused the failure of most of their higher education reforms. This state of affairs forced some concerned academics to react.

Key words and expressions: lifelong learning, higher education, work-related learning, learning for employability, branding, New Labour, misinterpretation, market-economy.
\end{abstract}

\section{Samih AZOUI}

Département d'Anglais

L'école supérieure de Constantine (Algérie)

\section{ملغص Introduction :}

يتناول هذا المقال موضو عا أثار وماز ال يثير اهتمام

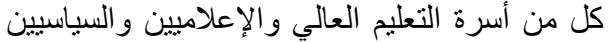

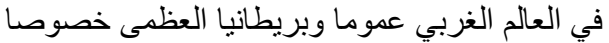

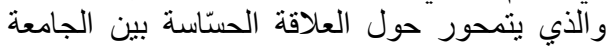

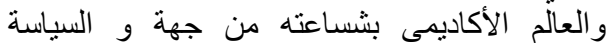
برجالها وأحزابها من جهة أخرى بهدف تسليط الضوء على الأسباب التي دفعت بالحكومة البريطانية

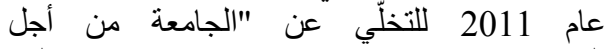
الصناعة" (the University for Industry) التي

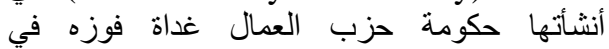

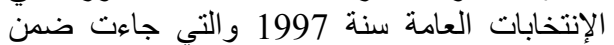
مخطط الإصلاح الجامعي تحت شعار "التعلم مدى هاعت

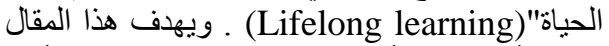

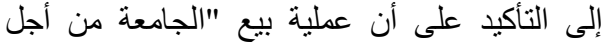

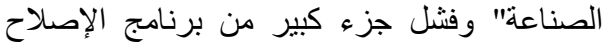

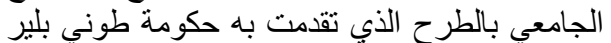
(Tony Blair)

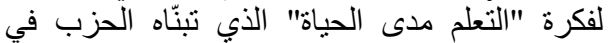
أجندته السياسية والمبنية على إقتصاد السية السوق مستنداه

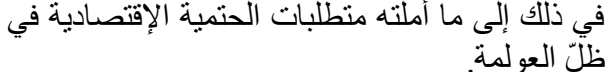

This article explores the thorny relationship between politics and academia in Britain. It attempts to provide a rationale for the recent British government disposal of the last of the over-publicised New Labour projects, the University for Industry, which was part of the plan to reform UK Higher education by the close of the $20^{\text {th }}$ century and opening of the $21^{\text {st }}$ formally known as lifelong learning. The line of reasoning rests on the contention that New Labour's misinterpretation of the 'concept' of lifelong learning sealed the fate of reforms of higher education launched after the Party's victory in the general elections of 1997. 
The structure of the article takes it from the main event, which is the sale of Ufi Limited; then offers a concise review of the reasons why New Labour adopted a workbased interpretation of lifelong learning as the main assumption for their higher education reforms. The core of the argument follows next; with due focus on the potential mismatch between the tight economic party-political agenda of New Labour, which led them to misjudgement, and the academics' concerns, which compelled some of them to ignite resistance. The suggestion made at the end is rather a call to chew on upcoming developments.

\section{The End of a 'Success (or Fiasco) Story'}

On October $4^{\text {th }}, 2011$, The Ufi Charitable Trust ${ }^{(1)}$ sold Ufi Limited, the company behind the UK's leading online learning provider learndirect, to LDC (Lloyds TSB Development Capital), the leading mid-market private equity arm of Lloyds Banking Group, for $£ 40$ million. Sarah Jones, Chief Executive of learndirect, declared rather hopefully that " $[\mathrm{t}]$ he change in ownership will allow us to reach more businesses and learners with a wider range of products and services, while continuing to deliver excellent training and raise standards across the sector." (2) Such was the end of another most advertised of New Labour's lifelong learning projects, University for industry, as initiated by Gordon Brown in 1998. It was then claimed to be "a huge online learning scheme to attract adults and young people into education and training to improve their job opportunities," ${ }^{(3)}$ and was proclaimed the second largest learning organisation in the world. ${ }^{(4)}$ However, it must be emphatically stressed that a year after it was launched, the government's lifelong learning package, which included Individual Learning Accounts (ILA), the e-university (UKeU) and the NHS "university", crashed. Some observers conclude that "New Labour became notorious for "spin and exaggeration" in its public policy."(5)

\section{What Happened?}

Let's take it from the beginning. Lifelong learning became suddenly trendy in the sphere of British higher education policy-makers during the 1990s, more so when New Labour made of it a focal point in its higher education strategy, as stated by the Labour secretary of state for education and employment, David Blunckett, in his foreword to the 1998 Green Paper on lifelong learning:

To cope with rapid change and the challenge of the information and communication age, we must ensure that people can return to learning throughout their lives. We cannot rely on a small elite, no matter how highly educated or highly paid. Instead, we need the creativity, enterprise and scholarship of all people.

As well as securing our economic future, learning has a wider contribution. It helps make ours a civilized society, develops the spiritual side of our lives and promotes active citizenship. Learning enables people to play a full part in their community. It strengthens the family, the neighbourhood and consequently the nation. It helps us fulfil our potential and opens doors to a love of music, art and literature. That is why 
we value learning for its own sake as well as for the quality of opportunity it brings. ${ }^{(6)}$

These two paragraphs suggest that lifelong learning is a new paradigm that stands for the junction of liberal adult education and continuing professional education on one hand; and the parallel informal system of training in industry, business and the professions, on the other. ${ }^{(7)}$ The emphasis of New Labour's on Work-related learning, it must be recalled, sprung from the need for more and better-trained employees in response to the needs of an increasingly sophisticated economy, which itself was at the origin of the creation of polytechnics during the 1970s and their merging with the old university sector after the reforms of 1992, thus changing the profile and culture of higher education.

The University for Industry was launched shortly after the Labour Party 1997 election victory. A prospectus was issued in 1998 inviting potential partners to work with the UfI. The formal launch took place in 2000. The new project is the concretization of the Party's "education, education, education" priorities for adults and part of the learning age political manifesto aiming at engaging people in a learning life. To quote the pathfinder prospectus published earlier that year: "The UfI is at the heart of the government's vision for lifelong learning. It will be a public-private partnership to boost the competitiveness of business and enable individuals to improve their employability." ${ }^{(8)}$ As stated in the UfI pathfinder prospectus (1998), the New Labour government, and particularly the exchequer, Gordon Brown, intended the UfI to attain two strategic objectives: "To stimulate demand for lifelong learning among business and individuals;" and "[t]o promote the availability of, and improve access to, relevant, high-quality and innovative learning, in particular through the use of information and communications technologies." ${ }^{(9)}$

The first objective indicates that the UfI was to be a marketing organisation. It was for UfI's partners (Further Education Colleges, private and corporate training organisations and a few universities) to deliver courses and training. The New Labour's theoretical driving force was that adoption of up-to-date marketing techniques would stimulate the demand for lifelong learning. According to Sir Peter Scott, Tony Blair's Government focused on skills rather than people, and partnerships between the public and private sectors rather than the development of the State system of education, for greater economic competitiveness. ${ }^{(10)}$

The second objective stated in the prospectus emphasised that the UfI was to drop conventional institutional settings and face-to-face teaching. The emphasis was on "distributed" delivery at a diversity of "sites", and on "distance" delivery through computers and other media. ${ }^{(11)}$

Taken as a whole, the prospectus suggests that the UfI's prime mission was to remedy deficits in basic skills in information and communications technologies, to stimulate demand for training in small and medium-sized businesses and to meet the needs of specific industrial sectors such as automotive components, multimedia, environmental technology and services and distributive and retail trades. ${ }^{(12)}$ Put simply, this is work-related learning. 
Some critics already sounded the alarm on the already foreseeable failure of the UfI. Donald Macleod, head of communications for the Russell group of universities, explained in December 2004 how the ambitious government e-learning (learndirect) initiative had cost the taxpayer $£ 1$ bn but failed to attract private investment. He also reported that since April 2000 UfI had supported 1.4 million learners, but only $65 \%$ of students completed their courses by the end of 2004. ${ }^{(13)}$ In the opening section of the report of the Committee on Public Accounts, it is publicly stated that: "In seven years Ufi has provided over 4 million courses to 1.7 million people up to July 2005, twothirds of whom had not done any learning in the previous three years." And that: "Only $37 \%$ of small and medium-sized businesses know that learndirect is intended to support them and only 4\% use it."(14) On Monday 21 November 2005, Mr. Edward Leigh, Chairman of the Committee of Public Accounts, addressed Ms. Sarah Jones, chief Executive of UfI/learndirect: "[Y]ou were set up in 1998, by 2005 you had spent the best part of a billion pounds, $£ 930$ million, but only $37 \%$ of employers know about your business services. How can this be value for money?" She answered him: "We clearly recognise that now, as we start to mature our organisation, we have a lot more to do in addressing the needs of the SME market."(15) John O'Leary asserts that the New Labour's University for Industry was prone to fail because it "never focused on university-level courses and only became a mass provider of adult education when it switched to the 'learn direct' rubric." ${ }^{(16)}$ Something must have gone wrong.

\section{Misconception}

One possible reason that could have contributed to the failure of this enterprise is the complexity of the idea of lifelong learning, which is arguably beyond the reach of New Labour politicians, and any other politician for that matter, as long as they are holding to a rigid, and by the same token superficial, market-driven higher education policy. Lifelong learning is a complex idea, not as simplistic and somewhat vague as David Blunket suggests above: to learn throughout one's life. Prof. Peter Jarvis, adult and continuing education as well as lifelong learning specialist, provides a plethora of sub-concepts that contribute in the piecing up of the main concept of lifelong learning: (1) self-oriented/directed learning by means of libraries, museums, the media (including the World Wide Web), travel (as seen in European Union programs of Erasmus, Grundtvig, Socrates), visits and study tours; (2) distance education; (3) learning for employability (work-related learning); (4) education for leisure and education as leisure; (5) pre-retirement and post-retirement education; (6) liberal adult education; (7) education and the elderly; (8) hobby-type education; (9) access and return to study courses. ${ }^{(17)}$

Furthermore, it seems that the difficulty at establishing a clear and precise definition is but a scratch on the surface. Professor John Field, lifelong learning specialist, confesses that 'lifelong learning' is "a loose and ill-encompassing term, stretching way too far to have much purchase on reality." (18) Because it emphasizes learning rather than education or teaching, lifelong learning draws attention to "the University of Life."(19) In the same breath, Sir Peter Scott, Vice-Chancellor of King's College, London, contends that Lifelong Learning stretches out of a philosophy much wider than the organisational institutions could confine. He interestingly prefers to refer to Lifelong learning in terms of plans — not definitions. The idea of lifelong 
learning, he asserts, "is an educational aspiration," and "is present in all "learning organisation', private as well as public; in the mass media; and in the cultural exchanges in which we all engage...."(20) Lifelong learning focuses on "opportunity and progression, empowerment and enlightenment." He adds that "lifelong learning is not a peripheral activity in universities, still less a rival operation. It embraces, and suffuses, all their work from pre-degree to post-doctoral."(21) The role of universities, therefore, is to enhance an "access culture" into higher education; to open up regular courses to a wider range of people following the old extra-mural tradition much cherished by David Blunkett (see his statement in The Learning Age Green Paper); and last but not least, to continue to broaden postgraduate education. He concludes that all this "require an imperative shift in the government's obsession with counting qualifications and measuring outcomes," ${ }^{22}$ which it should be stressed is the politicians' forte.

Yet, there must be at least one workable definition that could be considered. The most thorough attempt is that provided by Peter Jarvis. He defines lifelong learning as: the combination of processes throughout a lifetime whereby the whole person - body (genetic, physical and biological) and mind (knowledge, skills, attitudes, values, emotions, beliefs and senses) - experiences social situations, the perceived content of which is then transformed cognitively, emotively or practically (or through any combination) and integrated into the individual person's biography resulting in a continually changing (or more experienced) person [italics original]. ${ }^{(23)}$

If anything, this definition tells much of the convolutions of this concept that those politicians obsessed with statistics and economic agendas will find all the pain in the world to bring it close to what they think is the reality.

Yet, it must be admitted that it is in the name of 'reality' exigencies that modern times democratisation of (higher) education in the western world reached unprecedented proportions. Tom Bentley, special adviser to David Blunkett, is of the thought that this new idea of lifelong learning springs from the realistic recognition of the growing importance of education, which is the outcome of four factors. The first is that 'human know-how' has become the basic resource of economic production compared to land, labour and capital in the past. As sociologist Peter Drucker put it in 1993, "knowledge is the only meaningful resource today. The traditional 'factors of production'-land (i.e., natural resources), labor, and capital-have not disappeared, but they have become secondary. They can be obtained, and obtained easily, provided there is knowledge."(24) The second is that educational opportunity has become a fundamental determinant of income and chances in life as job acquisition on the basis of manual skills has diminished. The third is the fact that there is relentless emphasis of government and business on innovation and productivity to avoid obsolescence. "[A]s knowledge becomes more accessible," says Tom Bentley "its content becomes less valuable, both because it is more easily available and because it becomes redundant more quickly." The fourth is simply that knowledge stirs the desire for more learning. ${ }^{(25)}$ 
It can be assumed therefore that lifelong learning presupposes that people will frequently return to formal education and training long (or short) after the completion of any course of study. This entails that learning becomes part and parcel of their professional activities; hence work-based learning. Indeed, and as Bentley observes, "[b]y the end of a four-year engineering degree, half the knowledge gained in the first year will be obsolete,"(26) which brings to the fore the possibilities that an extended "third age" offer to sustain recreational learning and transmit the skills and experiences that individual professionals gained during the larger part of their lives. ${ }^{(27)}$ Peter Jarvis shares the same point of view when he argues that "most of today's citizens' only property is their skill which can keep them in a job for a period of time. In this sense, lifelong learning is an investment through which citizens acquire the necessary skill to remain employable for the next few years."(28)

The heavy government investment in the over-publicised projects of a University for Industry and a National Grid for Learning and Individual Learning Accounts suggest strongly that learning for employability is Tony Blair's interpretation of lifelong learning, especially that he emphasised partnership with the private sector, being the obvious beneficiary. Could Blair and the think-tank actually be wrong in their interpretation? It must be admitted that globalisation has inaugurated a new economic age (a new reality!) It is part of this new economic reality that western nations should remain competitive in a world of interconnected communities and organisations. This new reality compels those western nations to adopt new economic strategies that could not be efficient without the elaboration of responsive education and training systems. This new reality also suggests that the world is shifting from the industrial age into the 'knowledge society' making of knowledge a valuable economic good and the 'knowledge worker' an active agent in the developed capitalist economies. ${ }^{(29)}$ Therefore, this 'economic Darwinism' compels UK, and all western economies, to develop high level skills and facilitate the production and transmission of knowledge and information.

The important role of vocational training in keeping pace with the changes that globalisation brought about and simultaneously responding to the new economic exigencies is undeniable. This finds substance in the opening section of the Dearing $\underline{\text { Report: }}$

People will need the knowledge and skills to control and manage their working lives. This requires a learning society which embraces both education and training, for people at all levels of achievement, before, during and, for continued personal fulfilment, after working life. ${ }^{(30)}$

It comes out that the development of work organisations and careers entails a flexible workforce with a grown faculty of adaptability to changing economic realities that could only be enhanced by post-qualifying training and education and, if necessary, total re-skilling for new jobs. ${ }^{(31)}$

The focus of Tony Blair, and after him Gordon Brown, on work-related learning as being the quintessence of lifelong learning has proved to be superficial and has triggered some enlightening academic reactions. Contrary to the New Labour's 'utilitarian' philosophy, Frostd and Taylor, assert in their research that any "serious" 
consideration of lifelong learning should imply a radical reordering of higher education, which Peter Scott actually predicted. ${ }^{(32)}$ They propose a neo-socialist and egalitarian interpretation of lifelong learning, making of it a tool for social inclusion, empowerment and democratisation. From the outset, they warn, this interpretation runs counter to the 'liberal' view (learning for personal development and enlightenment), the neo-liberal view (learning for personal material benefit and for free market economy), and the postmodern view (learning for the construction of a knowledge society). To straighten out misconception, they insist that the fundamental characteristics of lifelong learning should include a set of singular and challenging elements. ${ }^{(33)}$

First, the university can no longer be perceived as an ivory tower. That is, all universities have to enter into symbiotic partnership arrangements with organisations outside the university to respond to the perceptions, attitudes and culture of their entire communities. This, it must be stressed, is difficult to achieve as this assumption runs counter to the tradition of academic freedom. ${ }^{(34)}$

Second, the teaching function in universities must change so that the learning context becomes more learner-centred and the learner/student is empowered as a consumer. Again this is fraught with serious problems revolving around a central issue: that of defining the limits of the consumer's (learner's) right to determine the curriculum and to choose the appropriate programmes regardless of the other consumers, logically sharing the same right. This evokes the question of the degree of autonomy of both the university and the academic staff, suggesting the possible transformation of the university into a post-Fordist organisation. ${ }^{(35)}$

Third, the university and its learning programmes, structures and pedagogic practice must become more flexible. ${ }^{(36)}$

Finally, and most importantly, there is the issue of 'social purpose'. Lifelong learning is said to be concerned with the personal development of the individual learner in a work-related context that obviously must be beneficial to the employer. This should not exclude emancipation and empowerment of other social groups as part of a collective social change to create a more equitable and democratic society. If not, Frostd and Taylor argue, the new post-Fordist university could simply reproduce social divisions much the same as the traditional university. ${ }^{(37)}$ The key implication, according to Frostd and Taylor, is partnership with private enterprises. Therefore, failure in establishing partnership leads irrevocably to the failure of the whole lifelong learning, at least in the form the New Labour conceived of it. And actually this is what happened to the University for Industry as almost none of the conditions presented above were provided to ensure its success.

It must be paradoxical to discover that The University for Industry is a misnomer. According to Celia Weston, the UfI is "neither a university nor exclusively for industry." (38) In fact, it is not a university in the conventional shape. The use of "university" in its working title and initial prospectus suggests the insertion of the obsessive market preoccupation of "branding" in the public sector, as "university invokes public confidence and a perception of high quality and high perception." (39 It also suggests the need for previously neglected forms of education and training. ${ }^{(40)}$ 
Even from a market economy perspective (New Labour politicians' reality), the factual capability of the UfI to stimulate demand was unrealistic the time it was conceived of as long as education and training opportunities in many key domains exceeded demand. Dr. Anne Wright, head of the transition team of the UfI's headquarters in Sheffield, argued then that "[e]ncouraging people to understand the need to update their skills is the main challenge." And added that "[i]nteresting new learners is absolutely central to the UFI's work." ${ }^{(41)}$ On the face of it, courses and training were plentiful especially at the lower end of the skills market. Just like Alan Smithers, the Sydney Jones professor of education, ${ }^{(42)}$ Wright is convinced that to raise awareness of the opportunities available and "to provide learning that is relevant, flexible, affordable and fun" require a big publicity campaign, and efficient use of technology, in addition to partnerships with education and training providers, and with business and unions. ${ }^{(43)}$ Yet, its architect Josh Hillman, a former senior fellow at the Institute for Public Policy Research, has warned that "[i]f it becomes merely a branding device for college-based and open learning provision in lower-level skills, it will never be able to capture the public imagination and spearhead a national learning crusade as envisaged by Gordon Brown."(44) In fact, doubts about the ability of the UfI brand to seduce new customers have tended to repel training providers, colleges and universities. $^{(45)}$ It seems that the brand "university", which normally should be a good selling device, fell even short of advertising for an uninteresting, and therefore unmarketable, good!

\section{Misjudgement or Confusion?}

New Labour's superficial understanding of the concept of lifelong learning has led to misjudgement, not confusion. According to Sir Peter Scott, British ministers saw further education, not higher education, as the engine of lifelong learning, partly because of the elitist image of the university they still had in mind, and partly too because they were still influenced by Thatcherite measures of success and tend to plan according to quantitative targets. Still according to Scott, while Britain was by the end of the 1990s producing more university graduates than France, thus meeting the international standard in higher education, it still lacked intermediate qualifications. The other priority then was to produce more technicians and by the same token bring people who leave education in their early teens with inadequate qualifications up to international standards; and, according to ministers, this was the mission of further education. ${ }^{(46)}$ As a matter of fact, Ministers saw lifelong learning in terms of social equity; while its main focus, argued Scott, must be on the young, white, working-class males unreached in one way or another by successive post-war educational reforms. It is easily accepted that lifelong learning should target first and foremost the socially disadvantaged. But if the aim is to create a lifelong learning culture as announced in the New Labour Party manifestoes, "the target groups," argues Peter Scott, "are as likely to be found in the suburbs as in the inner cities, in saloon bars and golf clubs as in employment offices and community centres." He rhetorically asserts: "It is Middle England, comfortable, complacent, a little philistine, that really needs wooing to lifelong learning." (47)

As David Cameron's government, for its turn, is tinkering with the growing problems that higher education is facing up to, a group of concerned dons, including 
Sir Peter Scott, decided to argue back on reforms. They call themselves The Council for the Defence of British Universities (CDBU). Their common bond is "their distaste for treating a university education as a mere commodity, an idea that appears to be the heart of the government's reforms."(48) If the university teachers will not spearhead the 'real' and thoughtful 'offensive', who else will do?

\section{Conclusion}

The New Labour government announced the University for Industry in 1998, and launched it in 2000. Since then it was a bottomless pit, gulping down, at least up to 2005, shy of a billion pounds and making trivial revenues. It neither succeeded as a marketing organisation, nor could it attract partners. It was not even close to cater for needs in basic skills in information and communications technologies, let alone to stimulate demand for training in small and medium-sized businesses or meet the needs of specific industrial sectors. Ufi Limited was finally sold in 2011. The argument so far has been that the failure of this enterprise, and the whole lifelong learning plan, could be attributed to New Labour's short sightedness and misunderstanding, as compared to the complexity of the idea of lifelong learning, that actually led to misjudgement. Despite the market economy reality as dictated by globalisation, lifelong learning means way more than learning for employability and vocational training. Given that David Cameron's government is "dilly dallying", it is interesting to observe the evolution of resistance in some quarters of academia in Britain, and, so, foretell the course of action.

\section{Bibliography}

Bentley, Tom. "The New Landscape of Learning," New Statesmen, Special Supplement: $\begin{array}{lllll}\text { Lifelong Learning, UK } & \text { universities } & \text { Nov. } & 13, & 1998\end{array}$ <http://www.findarticle.com/p/articles/mi_m0FQP/is_4411_127/ai_53290554/print> (retrieved 13/02/2008 23:05).

DfEE, The Learning Age: A Renaissance for New Britain. London: DfEE, 1998.

Drucker, Peter. Post-Capitalist Society. New York: Harper Business, 1993.

Field, John. Lifelong Learning and the New Educational Order. Staffordshire: Trentham, 2006.

Frostd, Nick, and Richard Taylor, "Patterns of change in the university: the impact of 'Lifelong Learning' and the 'World of Work'." Studies in the Education of Adults, Vol. 33, $\mathrm{N}^{\circ} 1$, (Apr. 2001), pp. 49-59.

Hillman, Josh. University for Industry: Creating a National Learning Center. London: institute for public Policy Research, 1997.

House of Commons, Committee of Public Accounts. Extending access to learning through technology: Ufi and the learndirect service. London: The Stationary Office Limited, 2006.

Jarvis, Peter. ADULT EDUCATION AND LIFELONG LEARNING: Theory and Practice. $3^{\text {rd }}$ ed. London: Routledge Falmer, 2004.

- Democracy, Lifelong Learning and the Learning Society. London: Routledge, 2008. Vol. 3 of Lifelong Learning and the Learning Society. 3 vols.

- Globalisation, Lifelong Learning and the Learning Society. London and New York: Routledge, 2007. Vol. 2 of Lifelong Learning and the Learning Society. 3 vols.

Macleod, Donald. “'University for Industry' failed to attract private cash" <http://WWW.guardian.co.uk/education/2004/dec/10furthereducation.uk/print> (retrieved 16/05/2009 13:20). 
O’ Leary, John. “Higher education.” In Blair's Britain, 1997-2007, ed. Anthony Seldon. Cambridge: CUP, 2007. Pp. 468-84.

Samih, Azoui. "An Analysis of Some Aspects of Change and Permanence in the English Higher Education: Democratisation and its Ramifications." Doctorat Es-science thesis. University of Mentouri, 2012.

Scott, Peter. "Academics have started to argue back on higher education reforms," The Guardian, 12 Nov. 2012 <http://www. Theguardian.com> (retrieved 06/08/2013 13:26).

. "Is Higher Education an Anachronism? The Development of a Comprehensive PostSchool System in Britain." Revue Française de Civilisation Britannique. vol. x, N 3 . Paris : CRECB, 1999. Pp. 107-20.

. "Out of the Ivory Tower," New Statesmen, Special Supplement: Lifelong Learning, UK universities 13 Nov., 1998

<http://www.findarticle.com/p/articles/mi_m0FQP/is_4411_127/ai_53290554/print〉 (retrieved 13/02/2008 22:55).

Smithers, Alan. "The Tale of an Educational Nonsense," New Statesman, Special Supplement: $\begin{array}{lllll}\text { Lifelong Learning, vocational education } & \text { Nov. } & 13, & 1998\end{array}$ <http://www.findarticle.com/p/articles/mi_m0FQP/is_4411_127/ai_53290555/print> (retrieved 13/02/2008 22:43).

The National Committee of Inquiry into Higher Education, The Dearing Report (1997) Higher Education in the learning society, Main Report. London: Her Majesty's Stationery Office, 1997.

"Ufi Charitable Trust sells Ufi Ltd and learndirect to LDC", May 10 2011, <http://www.ufi.co.uk/news/ufi-charitable-trust-sells-ufi-ltd-and-learndirect-ldc> (retrieved 06/08/2013 13:15).

Weston, Celia. "A New Acronym for Industry," New Statesmen, Special Supplement: Lifelong $\begin{array}{lllll}\text { Learning, UK } & \text { universities } & \text { Nov. } & 13, & 1998\end{array}$ <http://www.findarticle.com/p/articles/mi_m0FQP/is_4411_127/ai_53290563/print> (retrieved 13/02/2008 22:40). 
$\underline{\text { Notes }}$

1-The Ufi Charitable Trust is a company limited by guarantee and a registered charity, which was set up in 1998. Ufi aims to deliver a step change in adult learning and employability for all in the UK through the adoption of 21st century technologies. Prior to the sale, Ufi Charitable Trust owned and oversaw the management of Ufi Ltd, the organisation behind learndirect.

2-"Ufi Charitable Trust sells Ufi Ltd and learndirect to LDC", May 10 2011, http://www.ufi.co.uk/news/ufi-charitable-trust-sells-ufi-ltd-and-learndirect-ldc, $\quad$ (retrieved 06/08/2013 13:15).

3-Ibid.

4-Ibid.

5-John O' Leary, "Higher Education,” in Blair's Britain, 1997-2007, ed. Anthony Seldon (Cambridge: CUP, 2007), p. 479.

6- DfEE, The Learning Age: A Renaissance for New Britain (London: DfEE, 1998), p. 7.

7- P. Scott, "Is Higher Education an Anachronism? The Development of a Comprehensive PostSchool System in Britain.” Revue Française de Civilisation Britannique, vol. x, N 3 (Paris :

CRECB, 1999), p. 113.

8- In P. Scott, "Is Higher Education an Anachronism?" p. 112.

9- Ibid.

10- P. Scott, "Is Higher Education an Anachronism?” p. 113.

11- Ibid.

12-Ibid.

13- "University for Industry' failed to attract private cash" <http://WWW.guardian.co.uk/education/2004/dec/10furthereducation.uk/print> (retrieved 16/05/2009 13:20).

14- House of Commons, Committee of Public Accounts, Extending access to learning through technology: Ufi and the learndirect service (London: The Stationary Office Limited, 2006), p. 4.

15- p. 19

16- John O' Leary, op cit.

17- Peter Jarvis, ADULT EDUCATION AND LIFELONG LEARNING, Theory and Practice, 3rd edition (London: Routledge Falmer, 2004), pp.29-33.

18- John Field, Lifelong Learning and the New Educational Order (Staffordshire: Trentham, 2006), p. 2.

19- Ibid.

20- P. Scott, "Out of the Ivory Tower," New Statesmen, Special Supplement: Lifelong Learning, UK universities (13 Nov., 1998)

<http://www.findarticle.com/p/articles/mi_m0FQP/is_4411_127/ai_53290554/print> (retrieved 13/02/2008 22:55).

21- P. Scott, "Out of the Ivory Tower,"

22- Ibid.

23- Peter Jarvis, Globalisation, Lifelong Learning and the Learning Society, Vol. 2 (London and New York: Routledge, 2007), p. 1.

24- Post-Capitalist Society (New York: Harper Business, 1993), p. 42.

25- Tom Bentley, "The New Landscape of Learning," New Statesmen, Special Supplement: Lifelong Learning, UK universities (Nov. 13, 1998), <http://www.findarticle.com/p/articles/mi_m0FQP/is_4411_127/ai_53290554/print> (retrieved 13/02/2008 23:05).

26- Ibid.

27- Ibid.

28- Peter Jarvis, Democracy, Lifelong Learning and the Learning Society, Vol. 3 (London: Routledge, 2008), p. 48. 
29- Nick Frostd and Richard Taylor, "Patterns of Change in the University: The impact of 'Lifelong Learning' and the 'World of Work'," Studies in the Education of Adults, Vol. 33, $\mathrm{N}^{\circ} 1$, (Apr. 2001), p. 50.

30- The National Committee of Inquiry into Higher Education, The Dearing Report (1997) Higher Education in the learning society, Main Report (London: Her Majesty's Stationery Office 1997), p. $9,1.12$.

31- N. Frostd and R. Taylor, p. 50.

32- P. Scott, "Is Higher Education an Anachronism?" p. 113.

33- N. Frostd and R. Taylor, p. 51.

34- N. Frostd and R. Taylor, pp. 51-52; see also Peter Scott "Out of the Ivory Towers."

35- N. Frostd and R. Taylor, p. 52.

36- Ibid.

37- Ibid.

38- Celia Weston, "A New Acronym for Industry," New Statesmen, Special Supplement: Lifelong Learning, UK universities (Nov. 13, 1998), <http://www.findarticle.com/p/articles/mi_m0FQP/is_4411_127/ai_53290563/print> (retrieved 13/02/2008 22:40).

39- Josh Hillman, University for Industry: Creating a National Learning Center (London: institute for public Policy Research, 1997) p. 35; cf. the US Hotrod University.

40- P. Scott, "Is Higher education an Anachronism?" p. 113.

41- In C. Weston.

42- Alan Smithers, "The Tale of an Educational Nonsense," New Statesman, Special Supplement: Lifelong Learning, vocational education (Nov. 13, 1998), <http://www.findarticle.com/p/articles/mi_m0FQP/is_4411_127/ai_53290555/print> (retrieved 13/02/2008 22:43).

43- C. Weston.

44- In C. Weston.

45- P. Scott, "Is Higher Education an Anachronism?" pp. 113-14.

46- P. Scott, "Out of the Ivory Tower."

47- Ibid.

48- P, Scott, "Academics have started to argue back on higher education reforms," The Guardian, 12 Nov, 2012, <http://www. Theguardian.com> (retrieved 06/08/2013 13:26). 